\title{
THE ORIGINS OF HATE-CRIME LAWS
}

\author{
Kamban Naidoo*
}

Key words: Hate crime; hate-crime laws; history; origins

\section{Introduction}

The non-recognition of hate crime as a specific category of criminal conduct in South African law has prompted recent calls for the enactment of hate-crime legislation. ${ }^{1}$ A hate crime may be described as criminal conduct which is motivated

1 In this regard see Duncan \& Nel 2011: 33; Naidoo \& Karels 2012: 624; and Mollema \& Van der Bijl 2014: 679. See, also, Harris (accessed 11 Nov 2015). Most of the present South African public and academic debate surrounding the non-recognition of hate crime in South African law and the need for hate-crime laws concern sexual orientation in light of the rapes and murders of Black lesbian women. However, calls for hate-crime legislation also concern race and ethnicity following the large-scale outbreaks of xenophobic violence against black African foreigners in 2008 and 2015. It should be noted that despite the non-recognition of hate crime as a specific category of criminal conduct in South African criminal law, hate-speech provisions exist in South Africa. Sections 10 and 12 of the Promotion of Equality and Prevention of Unfair Discrimination Act 4 of 2000 (hereinafter referred to as the Promotion of Equality Act) contain specific prohibitions on hate speech. These provisions are applicable to the publication and dissemination of words and information that could incite harm or promote hatred towards a specific group of people. This statute provides a civil remedy for hate speech in the form of damages. The conduct that is prohibited by the Promotion of Equality Act does not, however, address physically violent and coercive criminal conduct that is motivated by prejudice or bias. The Promotion of Equality Act therefore does not afford protection to most victims of hate crimes in South Africa.

* Senior Lecturer, Department of Criminal and Procedural Law, University of South Africa.

Fundamina

Volume 22 | Number 1 | 2016

pp 53-66
DOI: 10.17159/2411-7870/2016/v22n1a4 Print ISSN 1021-545X/ Online ISSN 2411-7870 
by the perpetrator's prejudice or bias, commonly referred to as "hate", towards the victim's race, ethnicity, gender, sexual orientation, religion, disability and several other victim characteristics. ${ }^{2}$

A hate crime therefore consists of conduct which complies with the definition of a crime and which is motivated by the perpetrator's bias or prejudice against the victim. ${ }^{3}$ In most jurisdictions that recognise hate crime as a specific category of criminal conduct, laws have been enacted which create specific hate crimes ${ }^{4}$ and which allow sentencing officers to impose harsher sentences on convicted hate-crime perpetrators; these are referred to as aggravated or enhanced penalties. ${ }^{5}$

Several academic scholars agree that the United States of America has been at the forefront of the enactment of hate-crime legislation for more than two decades. ${ }^{6}$ While the recognition of hate crime as a category of criminal conduct undoubtedly has its roots in the United States of America, there is no consensus as to the date when criminal conduct motivated by specific prejudices or biases was first accorded such recognition in American history. ${ }^{7}$ This article attempts to trace the origins of both hate crime as a specific category of criminal conduct as well as hate-crime laws.

\section{Post-American Civil-War origins of hate-crime laws}

Several writers trace the origins of hate-crime laws to the post-Civil War period in the United States of America when the American Congress passed numerous federal civil-rights laws. ${ }^{8}$ Petrosino ${ }^{9}$ opines that the "antecedents" of present hatecrime laws can be traced to the post-Civil War or "Reconstruction" period which

2 Since hate crimes are crimes that are motivated by bias or prejudice, there is a tendency in some American literature to refer to hate crimes as "bias crimes". However the term "hate crime" will be used in this article.

3 In the context of hate-crime laws, the crime is referred to as the "underlying" crime, or the "base" or the "predicate" crime. The motivation is regarded as a "bias motivation". See, further, Lawrence 1999: 9 .

4 If, eg, a crime of assault is motivated by prejudice or bias towards the race of the victim, the bias motivation would render the crime a racially-motivated assault and consequently as a hate crime.

5 An aggravated or enhanced penalty is more severe than the penalty imposed on the same crime when it is not motivated by bias or prejudice towards the victim's race, ethnicity, sexual orientation, gender etc. See, in this regard, s 7 of the American statute, the Matthew Shepard and James Byrd Junior Hate Crimes Prevention Act of 2009 as well as s 28 of the British statute, the Crime and Disorder Act of 1998, which allow for the imposition of enhanced or aggravated penalties on convicted hate-crime perpetrators.

6 Levin 1999: 6; Gerstenfeld 2013: 31-32; Hall 2013: 18.

7 The earliest example of a contemporary federal hate-crime law in the USA is the Hate Crime Statistics Act of 1990. This latter Act may be considered as the first modern federal hate-crime law in the USA. However, as will become clear below, several American states had enacted their own hate-crime laws during the early 1980 s.

8 Levin 2002: 227; Hall 2013: 20; Gerstenfeld 2013: 12-13.

9 1999: 15. 
culminated in a number of legal reforms and constitutional amendments. A similar view is expressed by Levin ${ }^{10}$ who sees the "seeds" of present American hate-crime laws in post-Civil War laws which protected groups of people on the basis of their status, and in particular on the basis of their race.

The foundations of the American civil-rights model were laid during the postCivil-War period. The American Congress ratified several amendments to the Constitution: the Thirteenth Amendment in 1865 abolished slavery, the Fourteenth Amendment in 1868 granted citizenship to all persons born or nationalised in the United States of America and the Fifteenth Amendment in 1870 extended voting rights to citizens who were previously denied this right because of their race, colour or status as slaves. ${ }^{11}$ All the aforementioned Constitutional amendments included provisions for Congress to pass legislation to enforce the amendments at state level thereby removing the autonomy of states to deprive minorities of their rights. ${ }^{12} \mathrm{~A}$ number of federal statutes were subsequently passed during this period which supplemented and enforced the constitutional amendments and which protected newly-freed slaves, especially in the Southern states where they were "at best second-class citizens and at worst subject to harassment, intimidation and murder". ${ }^{13}$

The reluctance of state-level local authorities to prosecute crimes committed by Whites against Blacks ${ }^{14}$ led to the American Congress passing the Civil Rights Act of 1866 which established citizenship for all those born in the United States of America and the Enforcement Act of 1870, which guaranteed the rights of due process of law and equal protection of the law guaranteed by the Fourteenth Amendment, and the right to vote established by the Fifteenth Amendment. ${ }^{15}$

According to the Civil Rights Act of $1866^{16}$

all persons born in the United States and not subject to any foreign power, excluding Indians not taxed, are hereby declared to be citizens of the United States; and such citizens, of every race and colour, without regard to any previous condition of slavery or involuntary servitude, except as punishment for crime whereof the party shall have been duly convicted, shall have the same right in every State and Territory in the United States, to make and enforce contracts, to sue, be parties, and give evidence, to inherit, purchase, lease, sell, hold, and

$10 \quad 2002: 228$.

11 See Hall 2013: 21; Levin 2002: 231.

12 See Hall 2013: 21. Section 5 of the Fourteenth Amendment gave Congress the power to pass any laws necessary to enforce the amendment. See "Civil rights: An overview" (accessed $30 \mathrm{Jul}$ 2015).

13 Lawrence 1999: 122. Lawrence cites the examples of the 1866 New Orleans and Memphis riots in which many Blacks were killed, as well as the increasing attacks on freed slaves by the Ku Klux Klan and smaller organised hate groups such as the Knights of White Carmelia and the White Brotherhood (see, in general, Lawrence 1999: 199-200).

14 Jacobs \& Potter 1998: 36.

15 See Lawrence 1999: 22.

16 Quoted from "The Civil Rights Act of 1866" (accessed 30 Jul 2015). 
convey real and personal property, and to full and equal benefit of all laws and proceedings for the security of persons and property, as is enjoyed by white citizens, and shall be subject to like punishment, pains, and penalties, and to none other, any law, statute, ordinance, regulation, or custom, to the contrary notwithstanding.

In the above statute citizenship and class or group-based protection were extended to all races (except for certain categories of Native Americans or "Indians"), to former slaves and generally to people of colour.

Levin describes the period of Reconstruction as follows: ${ }^{17}$

New, sweeping Constitutional and statutory reforms cut off the traditional legal and political methods Whites relied upon to deprive Blacks of their rights ... although their initial success was fleeting, these new, egalitarian post-war reforms laid the foundation for changes that extended into the latter half of the next century, including the emergence of hate-crime laws.

The American Congress also passed the Civil Rights Act of 1871 which permitted the federal government to prosecute people who conspired to deprive others of their civil rights or to prosecute government agents who deprived persons of their rights. According to the Civil Rights Act of $1871^{18}$

[w] hoever, under colour of any law, statute, ordinance, regulation, or custom, subjects any person in any State, Territory, Commonwealth, Possession or District to the deprivation of any rights, privileges, or immunities secured or protected by the Constitution or laws of the United States, or to different punishments, pains, or penalties, on account of such person being an alien, or by reason of his colour, or race, than are prescribed for the punishment of citizens, shall be fined under this title or imprisoned for not more than a year, or both; and if bodily injury results from the acts committed in violation of this section, or if such acts include the use, attempted use, or threatened use of a dangerous weapon, explosives, or fire, shall be fined under this title or imprisoned not more than ten years, or both; and if death results from the acts committed in violation of this section or if such acts include kidnapping or an attempt to kidnap, aggravated sexual abuse or an attempt to commit aggravated sexual abuse, or an attempt to kill, they shall be fined under this title or imprisoned for any term of year or for life, or both, or may be sentenced to death.

Jacobs and Potter ${ }^{19}$ opine that the purpose of the Civil Rights Act of 1871 was to guarantee fair law enforcement irrespective of the race of the victim. Levin ${ }^{20}$ is of the view that these civil-rights laws consisted of "a protected group ... a covered activity ... and a prohibition on some type of detrimental conduct". ${ }^{21}$ The 1871 Act

17 See Levin 2002: 231.

18 Quoted from "The Civil Rights Act of 1871" (accessed 30 Jul 2015).

19 1998: 37.

20 2009: 4.

21 The "protected group(s)" refer specifically to persons of colour, freed slaves and aliens. The "covered activities" included the exercise of property rights, contractual rights, litigation and due process of law (in terms of the Civil Rights Act of 1866). The "prohibited conduct" included a general prohibition against violent behaviour, with or without the use of weapons, kidnapping and sexual abuse (in terms of the Civil Rights Act of 1871). 
further extended protection to classes or groups of people, in this instance to "aliens" and to persons on the basis of race and colour. According to Levin ${ }^{22}$ these laws "represented a newfound validation of federal authority in the area of criminal law and supremacy of national power over that of the states to protect minorities from the harms of race-based violence and discrimination". ${ }^{23}$

The American Congress also enacted the Ku Klux Klan Act of 1871 which expanded the federal government's power to intervene where states failed to protect the constitutional rights of its citizens. The Ku Klux Klan Act of 1871 permitted federal authorities to intervene in an enumerated list of activities where there was a conspiracy to violate civil rights, for example threatening government officials, intimidating witnesses and jurors at a federal trial, and interfering with a citizen's right to equal protection under the law and a citizen's voting rights. These were among the conspiracies that were practised by the Ku Klux Klan against Blacks. ${ }^{24}$

The American Congress further passed the Civil Rights Act of 1875 which provided for equal treatment of all races in public accommodation, facilities, transport and places of entertainment. ${ }^{25}$

Jacobs and Potter ${ }^{26}$ regard the various federal civil-rights laws referred to above as "federal-criminal civil-rights statutes" since they were the only option available to the federal government to ensure that crimes committed against former slaves at local and state level would be investigated and prosecuted. If state and local authorities had investigated and prosecuted crimes against former slaves there would have been no need for the enactment of these statutes. During the Reconstruction period one also finds some judicial recognition accorded to racial bias motivation albeit in a dissenting judgement only. According to Lawrence, ${ }^{27}$ Justice Bradley "anticipated the modern development of bias-crime law, reading the Thirteenth Amendment as a

$22 \quad 2002: 231$.

23 According to Hall 2013: 47, during this period of American history, a debate raged between states and the federal government over control of criminal law enforcement. According to Meese 1997: 6, the drafters of the American Constitution had intended crime and law enforcement to fall largely within the jurisdiction of states.

24 According to Lawrence 1999: 122-123, during the congressional debates on the Bill, the intention was to provide federal authorities with the right to intervene in a number of common-law crimes such as murder, arson and robbery. However, the Bill was amended and federal prosecution was then limited to the specified activities. Thus, rather than a broad, hate-crime law, the Ku Klux Klan Act of 1870 confined federal criminal jurisdiction only to cases of "rights-interference crimes".

25 According to the Civil Rights Act of 1875 "[a]ll persons within the jurisdiction of the United States shall be entitled to full and equal enjoyment of the accommodations, advantages, facilities and privileges of inns, public conveyances on land or water, theatres, and other places of public amusement, subject only to the conditions and limitations established by law, and applicable alike to citizens of every race and colour, regardless of any previous condition of servitude". It is submitted that the Civil Rights Act of 1875 is an early example of an anti-discrimination law.

26 1998: 36.

27 1999: 127. 
font of federal authority for all crimes committed with racial animus" in the case of United States $v$ Cruikshank. ${ }^{28}$

In the case of Cruikshank Justice Bradley opined that in order to federalise a common-law crime: ${ }^{29}$

There must be a design to injure a person, or deprive him of his equal right of the protection of the laws, by reason of his race, colour, or previous condition of servitude ... otherwise it is a case exclusively within the jurisdiction of the state and its courts.

According to Levin hate crimes belong to a "subset" of old civil-rights and antidiscrimination laws. ${ }^{30} \mathrm{He}$ therefore does not regard the present recognition of hate crime as a specific category of criminal conduct as a novel phenomenon. Jacobs and Potter ${ }^{31}$ however, argue that while federal civil-rights statutes dealt with issues of race and discrimination, as some hate-crime laws do, this is the only similarity that these laws have with the present American régime of hate-crime legislation. They further opine that the civil-rights statutes of the Reconstruction era were not aimed at hate crimes as the concept is presently understood, but were intended to deal with interference with a person's civil rights. Moreover, the federal civil-rights laws of the nineteenth century did not enhance penalties and recriminalise conduct already criminalised in law. 32

\section{The twentieth-century origins of hate-crime laws}

There is some suggestion that the recognition of hate crime as a specific category of criminal conduct and the origin of hate-crime laws may be traced to the postSecond World War period when bigotry based on race, ethnicity and gender were increasingly condemned by American society. ${ }^{33}$

During this period the state of Connecticut was one of the first American states to pass a statute which addressed the problem of "racially-motivated assaults". The Connecticut General Statute of 1949 "criminalised the ridiculing of an individual

28 United States $v$ Cruikshank 25 Fed Cases 707 (1874).

29 United States $v$ Cruikshank 25 Fed Cases 707 (1874) at 712.

30 2009: 3.

31 1998: 36.

32 Ibid.

33 This is an alternative view that is expressed by Jacobs \& Potter 1998: 5. According to Henderson 2010: 164, in order to avert a genocide like the Holocaust, a number of international treaties were negotiated in the post-Second World War period which were designed to eradicate incitement to racial discrimination (which, in turn, led to the 1965 International Convention on the Elimination of All Forms of Racial Discrimination) and to prohibit advocacy of national, religious and racial hatred (which resulted in the 1966 International Covenant on Civil and Political Rights). It would be trite to add that in the immediate aftermath of the Second World War there was increased international awareness of bigotry, prejudice and racism and the devastating consequences thereof. 
based on race, colour or creed". ${ }^{34}$ Petrosino ${ }^{35}$ suggests that the origin of modern hatecrime laws in the United States of America could also be linked to the 1954 United States Supreme Court decision in Brown v Board of Education of Topeka ${ }^{36}$ which overturned the "separate but equal" doctrine in American public schools. ${ }^{37}$

Some scholarly research traces the origins of hate-crime laws in the United States of America to the Civil-Rights Movement ${ }^{38}$ of the 1960s, the women's rights and the gay and lesbians' rights movement of the 1970s as well as the subsequent disabilities and victims' rights movement. ${ }^{39}$ Jacobs and Potter regard the Civil Rights Movement of the 1960s as significant since it resulted in the development of "identity politics" which they link to the modern hate-crime movement as follows: ${ }^{40}$

[I]dentity politics refers to a politics whereby individuals relate to one another as members of competing groups based upon characteristics like race, gender, religion and sexual orientation ... according to the logic of identity politics, it is strategically advantageous to be recognised as disadvantaged and victimised. The greater a group's victimisation, the stronger its moral claim on the larger society ... the current hate-crime movement is generated not by an epidemic of unprecedented bigotry but by heightened sensitivity to prejudice and, more important, by our society's emphasis on identity politics.

According to Hall, ${ }^{41}$ after the Civil-Rights Movement there followed a shift in thinking in relation to the treatment of certain minority groups. The advantages to be gained in recognising a group's prior mistreatment and victimisation included official recognition in a number of social contexts such as employment benefits, university admissions, the awarding of public contracts and the creation of voting districts. ${ }^{42}$ In terms of the logic of identity politics, "a group can assert a moral claim to special entitlements and affirmative action". ${ }^{43}$ In a similar vein, Jenness and Grattet write that ${ }^{44}$

34 See Lawrence 1999: 20. In this regard, refer to ss 53 to 57 of the Connecticut General Statute of 1949.

35 1999: 15.

36347 US 483 (1954).

37 While it is conceded that the case of Brown v Board of Education of Topeka marked a new, more liberal direction in the jurisprudence of the American Supreme Court, Petrosino does not provide any convincing proof that the origins of hate-crime laws can be traced to this period.

38 According to Shimamoto 2003-2004: 831, the Civil-Rights Movement refers to a period commencing in the early 1960s that was marked by violent protests and demonstrations, sit-ins and marches against racist practices and segregation in the USA.

39 See, eg, Jacobs 1992-1993: 542; Jacobs \& Potter 1998: 5; Grattet \& Jenness 2004: 23-24; and Jenness 2002: 19-22.

40 1998: 5-6.

41 2013: 23.

42 See Jacobs \& Potter 1998: 66.

43 Ibid.

44 2004: 26. 
The anti-hate crime movement emerged through a fusion of the strategies and goals of several identifiable precursor movements that laid the foundation for a new movement to question and make publicly debateable, issues of rights and harm as they relate to a variety of constituencies.

These diverse social movements, in asserting their respective demands, stimulated public discussions about violence based on prejudice and bigotry and began demanding legal changes, especially in criminal law, to address the problem. ${ }^{45}$ According to Jenness, ${ }^{46}$ these movements politicised and emphasised violence against minority groups because of their minority status: the Civil-Rights Movement politicised violence against racial minorities (such as police brutality against Blacks), the women's-rights movement politicised violence against women (such as rape and domestic violence), the gay and lesbian-rights movement politicised violence against homosexuals (such as "gay bashing") and the disabilities movement politicised violence against people with disabilities (such as "mercy killings"). The predominant issue that these diverse civil-rights movements had in common was the perpetration of violence against specific minority groups. A later social movement to have a significant influence on the development of hate-crime laws was the victims' rights movement which emphasised that the victims of crime, especially violent crimes, have the right to special assistance such as counselling services, increased participation in the criminal-justice process, civil remedies and other special protections. ${ }^{47}$ The modern anti-hate crime movement thus arose out of these diverse social movements representing the interests of different groups of victims who have been aptly referred to as "strange bedfellows". 48

A significant American law which was passed as a result of the Civil-Rights Movement and which may be considered as a precursor of modern hate-crime laws was the Civil Rights Act of $1968 .^{49}$ Although this Act was not aimed at hate crimes per se, it is considered as a "catalyst for modern hate-crime legislation". ${ }^{50}$ The Civil Rights Act of 1968 prohibits interference with a person's federally-protected rights in cases of violence or threats of violence because of a person's race, colour, religion or national origin. The federally-protected rights include, inter alia, the rights to vote, to public education, to participation in jury service, to interstate travel and access to public places and services. According to Wang, ${ }^{51}$ the Civil Rights Act of 1968 requires the defendant to have acted with a bias motive since it uses the words because of the victim's protected status and that prior to the creation of a purely

See Grattet \& Jenness 2004: 25-26.

2002: 20.

See Grattet \& Jenness 2004: 26.

See Jenness 2002: 21.

See Jacobs \& Potter 1998: 38.

See Hall 2013: 24.

2000: 1401. 
federal hate-crime law, the American federal government resorted to the use of this Act to prosecute hate crimes. The Civil Rights Act of 1968 places the onus on the prosecution to prove that the defendant was motivated by bias and attacked the victim who was engaged in a federally-protected activity. ${ }^{52}$

Jacobs and Potter ${ }^{53}$ write that the Civil Rights Act of 1968 was intended to provide a remedy for the violence that resulted from opposition to civil-rights marches, to voter registration and voting issues, to the admission of Black students to formerly all-white schools and universities and to efforts to abolish the laws that enforced segregation. However, the complicated nature of the Civil Rights Act of $1968^{54}$ and the high burden of proof required to secure convictions led to the emergence of statelevel hate-crime laws in the United States of America with less onerous evidentiary requirements. ${ }^{55}$

As the Civil-Rights Movement gained momentum, civil-society organisations such as the Anti-Defamation League ${ }^{56}$ and the Southern Poverty Law Centre ${ }^{57}$ began compiling statistical reports to establish the number and frequency of crimes motivated by prejudice, bias and bigotry. ${ }^{58}$ In 1981 the Anti-Defamation League, concerned by the rise in crimes motivated by racial and ethnic bias and prejudice in the United States of America, particularly anti-Semitic crimes, and the fact that media exposure, education and law enforcement were ineffective, drafted a model hate-crime statute which recognised racial, religious and ethnic biases. ${ }^{59}$ It should be noted at this point that gender and sexual orientation biases were only subsequently added to an amended model hate-crime statute. ${ }^{60}$ The model statute was intended to influence state legislatures and the Federal government to enact hate-crime laws. The Anti-Defamation League's model hate-crime statute had the desired effect since a number of state legislatures in the United States of America subsequently enacted laws based on the model statute. ${ }^{61}$ Shortly after the drafting of the Anti-Defamation

52 According to Wang 2000: 1402-1403, the Civil Rights Act of 1968 was a difficult statute to invoke in hate crimes since it required proof of bias motivation in order to fulfil the culpability requirements and that a victim's "enumerated right" had been interfered with or that the victim was engaged in a "federally-protected activity".

53 1998: 38.

54 Ibid.

55 See Hall 2013: 114.

56 The Anti-Defamation League of B'nai B'rith (or the ADL) is a civil-rights organisation that was formed in 1913, initially with a focus on anti-Semitism, but subsequently countering all forms of discrimination and infringements of civil rights. See Walker 1994: 18.

57 The Southern Poverty Law Center (SPLC) was formed in the southern American state of Alabama by a group of civil-rights lawyers in 1971. Its mission was to test civil-rights laws and to seek justice for the poor and disenfranchised. See Howard (accessed 30 Jul 2015).

58 See Grattet \& Jenness 2004: 26.

59 Freeman 1992-1993: 582.

60 See Grattet \& Jenness 2004: 27.

61 See Freeman 1992-1993: 583. 
League's model hate-crime statute in 1981, the states of Oregon and Washington passed similar laws. ${ }^{62}$ According to Gerstenfeld ${ }^{63}$ while many states used the AntiDefamation League's model as a prototype, they often made changes, while other states drafted their own original statutes. Gerstenfeld ${ }^{64}$ writes that this is the reason for the diversity of hate-crimes laws in the United States of America today.

Perhaps the most significant federal law of the modern hate-crimes era to be passed in the United States of America was the Hate Crime Statistics Act of 1990 which has been briefly referred to in the introduction to this article. What is particularly significant about this statute is that the term "hate crime" was first coined by three members of the House who were sponsoring the Bill when being debated in the American House of Representatives. ${ }^{65}$ Jacobs and Potter ${ }^{66}$ acknowledge representatives John Conyers, Barbara Kennelly and Mario Biaggi, who used the term "hate crime" in 1985 to refer to crimes motivated by racial, religious and ethnic prejudice.

From 1985, the term "hate crime" entered media and social discourse in the United States of America and appeared in eleven newspaper articles nationwide. ${ }^{67}$ Ehrlich $^{68}$ opines that his term "ethnoviolence" which had hitherto been commonly used to refer to criminal conduct motivated by bias and prejudice was replaced by the term "hate crime" since it was a term that appealed to issues of crime, law and social control which were considered as legitimate issues by the media popularising such issues. The Hate Crimes Statistics Act simply obliged the United States Department of Justice to collect statistics of hate-crime incidents across the United States of America. ${ }^{69}$

\section{Conclusion}

The origins of hate-crime laws and the recognition of hate crime as a specific category of criminal conduct are shrouded in some uncertainty. The existing research suggests that shortly after the American Civil War laws were enacted which provided for status-based protection. However, the federal civil-rights laws which were passed during this period of American history were intended to protect vulnerable groups on the basis of race or previous conditions of servitude but did not provide for enhanced or aggravated penalties. The ostensible precursor of modern hate-crime laws can be traced to the period of the Civil Rights Movement which culminated in the

62 See Gerstenfeld 2013: 31.

63 Ibid.

64 Ibid.

65 See Hall 2013: 25.

66 1998: 4.

67 Ibid.

68 2009: 18.

69 See Lawrence 1999: 22. 
enactment of the Civil Rights Act of 1968. This was one of the earliest American laws to specifically recognise criminal conduct motivated by prejudice or bias towards a victim based on the victim's race, colour, religion or national origin. However, the Civil Rights Act of 1968 also did not allow for the imposition of enhanced or aggravated penalties.

It is submitted that the criminalisation of conduct motivated by prejudice and bias (or "hate") and the imposition of enhanced or aggravated penalties for crimes that are motivated by racial, ethnic, gender or sexual orientation bias reflect the abhorrence with which such crimes are viewed by modern, democratic societies.

The imposition of enhanced or aggravated penalties therefore reflects modern society's denunciation of criminal conduct that is motivated by such biases. ${ }^{70}$ Since hate crimes that are motivated by the race, ethnicity or sexual orientation of the victim conflict with society's established, acceptable values, they may be punished more severely.

Since the enactment of the Hate Crimes Statistics Act in 1990 a number of federal hate-crime laws have been passed in the United States of America. Contemporary hate-crime laws recognise a wide spectrum of victim characteristics that includes race, ethnicity, religion, disability, gender and sexual orientation. These hate-crime laws include the Hate Crimes Sentencing Enhancement Act of 1994 and the Matthew Shepherd and James Byrd Junior Hate Crimes Prevention Act of 2009. To date, over forty-five American states and the District of Columbia have enacted hate-crime statutes based on the Anti-Defamation League's model statute. ${ }^{71}$ The American trend to enact hate-crime laws has had some international impact, particularly in Western democratic countries. In 1998 the United Kingdom passed the Crime and Disorder Act which is the British equivalent of a hate-crime law and in 2003 France passed its first hate-crime law, which is commonly referred to as la loi Lellouche. ${ }^{72}$

In South Africa, civil-society organisations have made several submissions to the Department of Justice which have recommended the enactment of hate-crime legislation. ${ }^{73}$ It is lamentable that these calls have not been heeded given postapartheid South Africa's status as a constitutional state and its commitment to equality. ${ }^{74}$ While hate-crime laws will not eradicate crimes motivated by bias and

70 In this regard, see Iganski 2002: 138.

71 See the "Website of the Anti-Defamation League" (accessed 1 Aug 2015).

72 Which may be translated as "the Lellouche law". The full title of the "Lellouche law" is Loi No 2003-88 du 3 février 2003. See Bleich 2008: 12.

73 Refer to the "Website of the Hate Crimes Working Group" (accessed 1 Jul 2015). As has been stated in the introduction to this article, these calls for the enactment of hate-crime laws should be considered in light of the crimes that have been perpetrated against black lesbian women and the large-scale outbreaks of xenophobic violence against black African foreigners in South Africa.

74 The Constitution of the Republic of South Africa, 1996, which includes a justiciable Bill of Rights, is regarded as supreme law. The right to equality is enshrined in s 9 of the Constitution. It is submitted that the victims of crimes motivated by race, ethnicity and sexual orientation cannot fully enjoy their rights as equal citizens in a democratic South Africa until the enactment of hatecrime laws. 
prejudice, the imposition of the criminal sanction and an aggravated penalty to such conduct may be considered as the ultimate "symbolic message" 75 that a government has at its disposal to try and change prejudiced attitudes and the manifestations thereof.

\section{Abstract}

Hate crimes were first recognised as a specific category of criminal conduct in the United States of America. Evidence of such recognition is supported by a number of state level and federal hate-crime laws that were enacted in the United States between the early 1980s and 1990s. There is a tendency in some American literature, however, to trace the recognition of hate crime as a specific category of criminal conduct to two specific historical time periods. The first historical period that is usually considered, is the nineteenth-century post-American Civil War period when federal civil-rights statutes were passed by the American Congress to protect vulnerable groups of people who were victimised because of their race and prior status as slaves. The second time period that is considered is the mid-twentieth century, post-Second World War era up to the period of the Civil-Rights Movement. Irrespective of the origins of hate crime as a category of criminal conduct, their recognition has spawned a new category of crime and criminal laws in the United States of America and internationally. Contemporary hate-crime laws recognise a wide spectrum of prejudices and biases. Despite the international trend, particularly in democratic Western nations towards the recognition of hate crimes and the enactment of hate-crime laws, the Republic of South Africa has yet to enact a hate-crime law.

\section{Bibliography}

\section{Books, journals and websites}

Bleich, Erik (2008) "Responding to racist violence in Europe and the United States" in

Goodey, Jo \& Aromaa, Kauko (eds) Hate Crime: Papers from the 2006 and 2007 Stockholm Criminology Symposium (Helsinki): 9-15

"Civil rights: An overview" (accessed 30 Jul 2015): available at http://www.cornell.edu/wex/ civil_rights

Duncan, Breen \& Nel, Juan N (2011) "South Africa - A home for all? The need for hate-crime legislation" SA Crime Quarterly 38: 33-42

Ehrlich, Howard J (2009) Hate Crime and Ethnoviolence: The History, Current Affairs and Future of Discrimination in America (Boulder, Colo)

Freeman, Steven M (1992-1993) "Hate-crime laws: Punishment which fits the crime" Annual Survey of American Law 4: 581-585

75 See Hall 2013: 124. 
Gerstenfeld, Phyllis B (2013) Hate Crimes: Causes, Controls and Controversies 3 ed (Thousand Oaks, Calif)

Grattet, Ryken \& Jenness, Valerie (2004) "The birth and maturation of hate-crime policy in the United States" in Gerstenfeld, Phyllis B \& Grant, Diana R (eds) Crimes of Hate: Selected Readings (Thousand Oaks, Calif): 23-44

Hall, Nathan (2013) Hate Crime 2 ed (Abingdon)

Harris, Bronwyn (accessed 11 Nov 2015) "Arranging prejudice: Exploring hate crime in postapartheid South Africa" available at http://www.csvr.org.za/docs/racism/arrangingprejudic. $p d f)$

Howard, Alan B (ed) (accessed 30 Jul 2015) "Website of the Southern Poverty Law Center" available at http://www.splcenter.org/who-we-are/splc-history

Henderson, Elizabeth K (2010) "Offended sensibilities: Three reasons why the Hate Crimes Prevention Act of 2009 is a well-intended misstep" Chapman LR 2: 163-195

Iganski, Paul (2002) "Hate crimes hurt more, but should they be punished more severely?" in Iganski, Paul (ed) The Hate Debate: Should Hate Be Punished as a Crime (London): 132144

Jacobs, James B \& Potter, Kimberley (1998) Hate Crimes, Criminal Law and Identity Politics (New York, NY)

Jacobs, James B (1992-1993) "Implementing hate crime-legislation, symbolism and crime control” Annual Survey of American Law 4: 541-553

Jenness, Valerie (2002) "Contours of hate crime politics and law in the United States" in Iganski, Paul (ed) The Hate Debate: Should Hate be Punished as a Crime? (London): 15-34

Lawrence, Frederick M (1999) Punishing Hate: Bias Crimes under American Law (Cambridge, Mass)

Levin, Brian (1999) "Hate crimes: Worse by definition" J of Contemporary Criminal Justice 15(1): 6-21

Levin, Brian (2002) "From slavery to hate crime-laws: The emergence of race and status-based protection in American criminal law" J of Social Issues 58(2): 227-245

Levin, Brian (2009) "The long arc of justice: Race, violence and the emergence of hate crimelaw" in Perry, Barbara et al Hate Crimes vol 1 (Westport, Conn): 1-22

Meese, Ed (1997) "Big Brother on the beat: The expanding federalization of crime" Texas Rev of Law and Politics 1: 1-23

Mollema, Nina \& Van der Bijl, Charnelle (2014) "Hate crimes: The ultimate anathematic crimes" Obiter 35(3): 672-679

Naidoo, Kamban \& Karels, Michelle (2012) "Hate crimes against black lesbian South Africans: Where race, sexual orientation and gender collide (Part 2)" Obiter 33(3): 600-624

Petrosino, Carolyn (1999) "Connecting the past to the future: Hate crime in America" $J$ of Contemporary Criminal Justice 15(1): 22-47

Shimamoto, Eric (2003-2004) "Rethinking hate crime in the age of terror" University of MissouriKansas City LR 72: 829-843

“The Civil Rights Act of 1871" (accessed 30 Jul 2015) available at http://www.arch.ksu.edu/ jwkplan/law/civil\%20rights\%20acts\%20of\%201866,\%2018) 
Walker, Samuel (1994) Hate Speech: The History of an American Controversy (Lincoln, Neb)

Wang, Lu-in (2000) "Recognising opportunistic bias crimes" Boston University LR 80: 1399-1435

"Website of the Anti-Defamation League" (accessed 1 Aug 2015) available at http://www.adl.org/ PressRele/HatCr_51/5635_51.htm

"Website of the Hate Crimes Working Group" (accessed 1 Jul 2015) available at http://www.hcwg. org.za/HCWG

\section{Legislation}

France

Loi No 2003-88 du 3 février 2003

South Africa

The Constitution of the Republic of South Africa, 1996

The Promotion of Equality and Prevention of Unfair Discrimination Act 4 of 2000

United Kingdom

The Crime and Disorder Act, 1998 (c 37)

United States of America

The Civil Rights Act of 186614 Stat 27-30

The Enforcement Act of 187016 Stat 140

The Civil Rights Act of 187117 Stat 13

The Ku Klux Klan Act of 187117 Stat 13

The Civil Rights Act of 187518 Stat 335-337

Connecticut General Statute of 1949 c 14

Civil Rights Act of 196882 Stat 73

Hate Crime Statistics Act of 199028 USC $§ 534$

The Hate Crimes Sentencing Enhancement Act of 199428 USC 994

The Matthew Shepard and James Byrd Junior Hate Crimes Prevention Act of 200918 USC $§ 249$

\section{Case law}

United States of America

Brown v Board of Education, Topeka 347 US 483 (1954)

United States v Cruikshank 25 Fed Cases 707 (1874) 